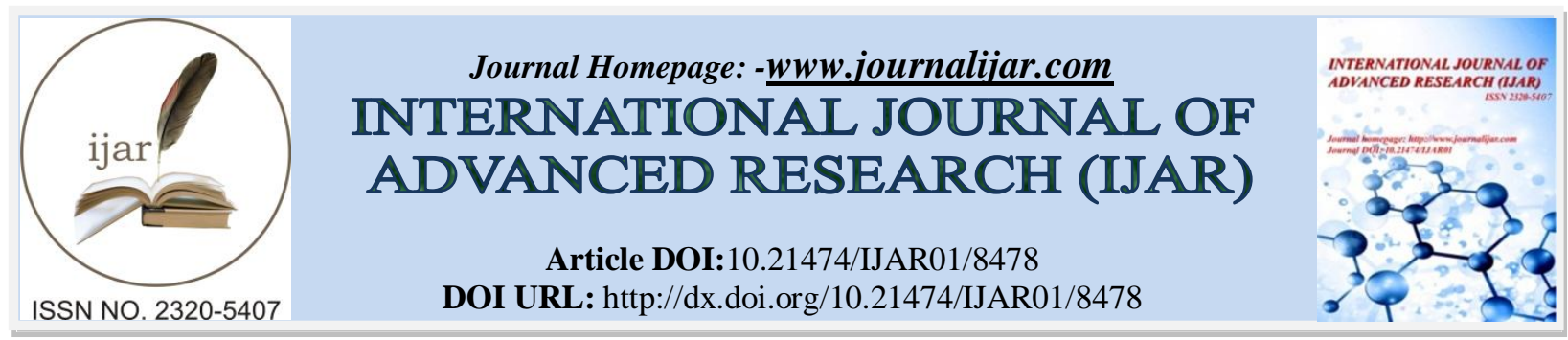

RESEARCH ARTICLE

\title{
THE MANAGEMENT MODEL OF BUDDHIST ORGANIZATIONSIN THAI SOCIETY.
}

NapoldechManilangca ${ }^{1}$, OrnpaphaChutikorntaweesin ${ }^{2}$ and ThuchaponYodthong ${ }^{2}$.

1. Doctoral Candidate, California University FCE, Los Angeles, California, USA.

2. Associate Professor, California University FCE, Los Angeles, California, USA.

\section{Manuscript Info}

Manuscript History

Received: 02 December 2018

Final Accepted: 04 January 2019

Published: February 2019

Key words:-

Management, Buddhist organizations, Thai society.

\section{Abstract}

The purposes of this research were 1) to study the management of Buddhist organizations in Thai society, and 2) to present the management model of Buddhist organizations in Thai society. The researcher applied quantitative research methods in conducting this research. The research results show that most respondents agreed with management of Buddhist organizations in Thai society at the highest level. In particular, International Organizational Management had the highest mean score, followed by Public Welfare, Non-Profit Organization, and Good Governance respectively.The hypotheses results show that with regard to the correlation between the components of management of Buddhist organizations in Thai society, the components had the relationship with the statistical significance at the level of .01.With regard to the statistics to evaluate the concordance of the model after the modification indices, the results show that Chisquare Probability Level was .057, CMIN/DF was 1.111, GFI was .948, and RMSEA was .015. This means the management model of Buddhist organizations in Thai society was relevant to the empirical data.

Copy Right, IJAR, 2019,. All rights reserved.

\section{Introduction:-}

The condition of Thai society has been changed into the direction of consumerism. The influence of this change or development leads to the competition of society of materialism. The business organization seizes opportunity to generate profits for their survival without any concern about stakeholders. This influence also causes an effect on the management of non-profit organization, such as the Buddhist organizations.

The Buddhist organization is one of the social institutes encountering the thinking dynamics, questioning about status, role, and appropriate education management, including the challenge on thought towards discipline and power relations in the culture of Buddhist organizations (PhraBrahmapundit (PrayoonDhammacitto), 2015). In Budha era, the management of Buddhist organizations mainly relied on Dhamma discipline. Regarding Buddhism in Thailand, the management of Buddhist organizations has been changed following the forms of governance. The benefits of present management of Buddhist organizations are the unity and the closeness with government; whereas the disadvantages are the mayhem against Dhamma discipline and the loss of people faith (Preechapermprasit, 2015). Besides, people do not go to the temple; which one of the reasons is the problem from management of Buddhist organization that was present by many kinds of media.

Corresponding Author:-NapoldechManilangca.

Address:-Doctoral Candidate, California University FCE, Los Angeles, California, USA. 
Nowadays, the feature and role of temple dramatically changed from the past. First, the temple becomes the residence of layman instead of monk and novice. Second, the temple that used to be a place of ordination for local people becomes a place of ordination for people from other places, which even the preceptor did not know their background. Third, the temple, which used to be a place of charity for local villagers according to the Theravada cult, has been changed to be similar to the Mahayana Buddhist monk's house. Forth, the temple, which used to be tidy, clean, cool and pleasant, becomes disorderly and dirty; thereby people lose faith and do not want to go to the temple. Fifth, the temple, which used to be the center of desirable social activities, becomes the source of amulet; some monk does not behave well or even violate the Buddha's teaching or destroy the people's faith. Some temple applied the business approach to attract people to donate money for material returns; some also built the sanctuary buildings more than necessary (PhraAkanitSiripanyo (Artwichai), 2011).

Moreover, the management structure of temple and the formatting of administration of Thai Buddhist monks are centralized. There is not the audit organization. The work isnot continuous. This leads to a lack of effectiveness in managing the activities of Buddhist monk.

In addition, the problem on public welfare that lacks management relationship for creating enough benefit for every part. Including that the management style of temple in present does not develop; the temple management strategies are not concrete; and the problem of temple management does not appropriately solved following the Buddhist direction (PhrakruVisuddhaNundhakun (SurasukVisuddhajaro), 2014).

From the above information, these problems are not correctly solved following the proper temple management principles. This might become a big reason leading or causing the damage or the decay of Buddhism in Thailand in the future (PhrakruVisuddhaNundhakun (SurasukVisuddhajaro), 2014). Therefore, the researcher realized the importance ofthese problems, and conducted the research about the management model of Buddhist organizations in Thai society, that perform public welfare missions without seeking for profits, and use the Buddhist good governance with international organization with systematic and standardized management in order to increase the faith towards Buddhist organization and the happiness of people in Thai society.

\section{Purposes of research:-}

1. To study the management of Buddhist organizations in Thai society.

2. To present the management model of Buddhist organizations in Thai society.

\section{Hypotheses of research:-}

H1 The components of the management of Buddhist organizations in Thai society have relationships with statistical significance.

H2 Public Welfare, International Organizational Management, Non-Profit Organization, and Good Governance are the variables affecting the management model of Buddhist organizations in Thai society.

\section{Research Paradigm:-}

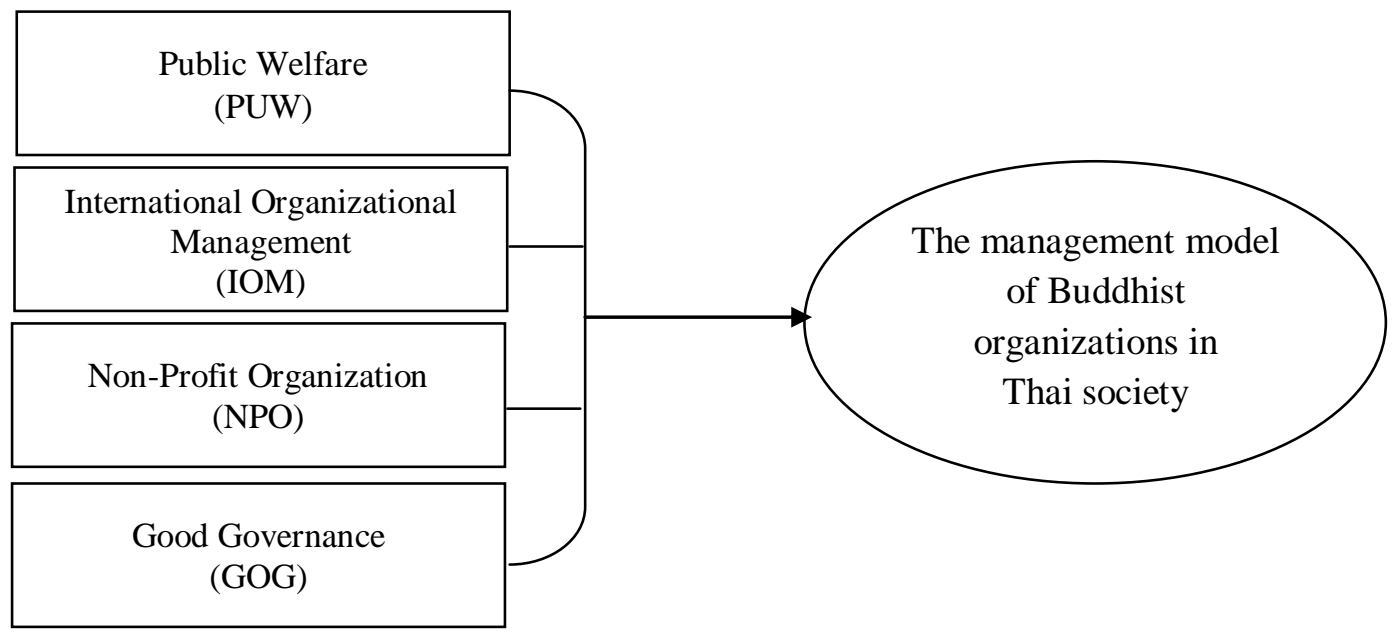

Figure 1:-Research Paradigm 


\section{Literature Review:-}

Concept about public welfarePublic welfare means to organize activities that are public benefits of agencies or groups of individuals or individuals that operate for the public interest, or the place that is public property of general people, or the public welfare that monks or temples operate nowadays. The objective is for the public interest (Department of Religious Affairs, 1985; PhrathepPariyatsuthi (WorawitKhongkhapanyo), 2002). The operation method of public assistance and public welfare to be in accordance with the regulations of The Sangha Supreme Council of Thailand can be categorized by its style as follows (Department of Religious Affairs, 1985); 1) business operation to help and support, 2) supporting the activities of business of others which are for public benefit, 3) supporting the places which are the public property,4) supporting the general people, and 5) housing assistance for the temple for further benefits. The importance of public welfare is as follows; 1) improving the quality of life and well-being of people, 2) developing and promoting morality in life, 3) being a quality mental development, 4) developing the intelligence to solve various problems and obstacles,5) coordinating to do some activities which leads to a better life, 6) to be able to solve problems and obstacles that occur, 7) making the society to live together happily, 8) beingconsidered as a source of merit, and 9) creating good deeds. To give assistance is broadcasted to every people; Buddha had His own teaching style or various forms of public welfare which can be divided in to 4 forms (PhrakhruPariyatThammawong, 2015); 1) discussion form, 2) lecturer form, 3) answerer form, and 4) Regulatory form. The teaching technics or the public welfare of the Buddha are (PhrakhruPariyatThammawong, 2015); 1) teaching from things that are easy to understand to things that are difficult to understand, 2) teaching the content by gradually increasing its complexity, 3) teaching by the real situation or direct experience, 4) teaching directly on the subject matter, 5) teaching with reason, so that the learners can think and realize by themselves, and 6) teaching only the necessary things that is sufficient for the learner to understand that topic.

\section{Concept about International Organizational Management:-}

Management means the process to work step by step, or the group of activities consisting of planning, organizing, leading/directing, and controlling. These have a direct relationship with organization resources in order to generate benefit, and to achieve an important goal of success according to the organization's goal effectively and efficiently. The activities of effective management are such as decision making in management, strategic management, human resource management, group management, and management in international environment (Schermerhorn, 1999; Serirat et al., 2002; Kaewchamnong, 2011; Drucker, 2006). In addition, Bartol and Martin (1997) suggested that the process of management consists of 4 important processes; planning, organizing, leading, and controlling; which these processes continually change following the organizational environment. Therefore, the executive must be always ready to handle changes. Fayol (1949) presented 14 management principles, and emphasized that they are flexible and able to be always adapted to demand. These 14 principles consists of division of work, authority and responsibility, discipline, unity of command, unity of direction, subordination of individual interests to general interests, remuneration, centralization, scalar chain, order, equity, stability of tenure of personnel, initiative, and esprit de corps. Moreover, Fayol also presented 5 elements of management, so called 'POCCC' (Sheldrake, 1996), which are 1) planning, 2) organizing, 3) command, 4) co-ordination, and 5) control. Gulick and Urwick (1937) presented 7 steps of management processes 'POSDCoRB', which consists of planning, organizing, staffing, directing, coordinating, reporting, and budgeting.

\section{Concept about non-profit organization:-}

Non-profit organization means the organization that can be founded by anyone or any group of people who have the same attitude. The objective must be to provide service to community without expecting a return. This kind of organization is a combination between the business organization and government organization due to the reason that the work is flexible under the management of committee who is volunteer or professional executives. The non-profit organization is an independent 'third sector', which means it does not under the governance of the government (Lohmann, 2007; McNamara, n.d.; Luckert, n.d.;Sornmanee, n.d.). According to Supajakwattana (2011),in addition that the non-profit organization must not seek for the profit, and should rely on the basis of organizational management, organizational design, performance assessment, including the qualifications of executives who have to work for others without expecting any return or profit. Above all, the most important is honesty and responsibility at the highest level. Moreover, the operation of non-profit organization must be transparent as well as the governance of government organization. Regarding the roles of non-profit organization, it should take part in supporting the project that the disadvantages are not treated equally from public or private sector, and in developing the social safety nets, in creating the system of social insurance for poor household. Chansom (2012) said that the financial management of both non-profit and profit organization are not completely different. The slight differences are about form of investment assets, sources of funds, and sources of income and expenses, especially the target setting 
in financial management. Therefore, to set the target of financial management to be in accordance with the organization objective is the mainly important issue of management. Normally, the non-profit organization must make the financial report, which its financial target is to achieve the objective of organization foundation. Regarding the temple, as one of the kind of non-profit organization, its target is to be the religious place, the mind center of Buddhist, the place for doing religious activities, including the residence for monk. Although the temple does not work for profit, it must have the appropriate direction for financial management following the financial management principles of non-profit organization for the transparency in operation which can be verified.

\section{Concept about good governance:-}

Good governance means the good way to govern the country and society, which is the important direction to organize the state society,private sector and the public sector to live together peacefully. The international good governance emphasizes the norm that sets the structure, process, and relationship among public sector, private sector, and people sector, in managing the economy, politics, and society of the country. This must be based on accuracy and righteousness, and prioritizes the participation of people as important. This will lead to the sustainable development of the country (Prime Minister's Office, 1999; Uwanno, 2002; Khwanmuang, 2005; Kaewphichit, 2008). The principle of good governance, as prescribed in Royal Decree on Criteria and Procedures for Good Governance, B.E.2546 (2003), consists of 6 principles: 1) rule of laws, 2) ethics, 3) transparency, 4) participation, 5) accountability, and 6) value of money (Uwanno, 1999). According to Suwanmongkol(2015), UNDP indicated 9 components of good governance: 1) participation, 2) rule of law, 3) transparency, 4) responsiveness, 5) consensusoriented, 6) equity, 7) efficiency and effectiveness, 8) accountability, and 9) strategic vision. In addition, UN ESCAP mentioned 8 components of good governance: 1) participation, 2) rule of law, 3) transparency, 4) responsiveness, 5) consensus oriented, 6) equity and inclusiveness, 7) effectiveness and efficiency, and accountability. Due to the reason that both world society and Thai society prioritize good governance, many scholars are interested in Buddhist principles. Comparing to the Buddhist principle, the dhamma that most scholars consider as good governance in Buddhism is Dasavidha-Rājadhamma ("tenfold virtue of the ruler") which composes of 1) Dāna (charity), 2) Sīla (high moral character), 3) Pariccāga (self-sacrifice), 4) Ājjava (honesty), 5) Maddava (kindness and gentleness), 6) Tapa (austerity, self-control, non-indulgence), 7) Akkodha (non-anger, non-fury), 8) Avihimsa (non-violence; non-oppression), 9) Khanti(patience; forbearance; tolerance), and 10) Avirodhana (non-deviation from righteousness; conformity to the law)(PhraBrahmagunabhorn (P.A. Payutto), 2014). In the society of monk that Buddha established, He set up a system of rules and regulations for the coexistence of human beings, based on the principles of truth in nature as a basis for all human beings to access the system of dhamma, which is called 'discipline'. The social development to be the social governance, which is one level of good governance nowadays, consists of 2 main parts: ideal dhamma which is principle or goal, and discipline which is systematization.

\section{Research Methodology:-}

The quantitative research method was applied in conducting this research. The secondary data were retrieved by reviewing concepts and theories from documents and related research. The primary data were collected by using the questionnaire as the research tool, which is divided into 3 parts. Part 1 is concerned about the demographic profiles of respondent. Part 2 consists of the questions about the management style of Buddhist organizations in Thai society. Finally, part 3 is the recommendation towards the management style of Buddhist organizations in Thai society. The research populations are 5,682,415 populations registered in Bangkok (National Statistical Office, 2017). The sample size is indicated by using the table of Taro Yamane, receiving 400 samples (Prutipinyo, 2010). The sampling method is non-probability sampling and accidental sampling with people who cooperate in answering questionnaire. 350 questionnaires were returned. The statistics used in analyzing data were frequency, percentage, mean, standard deviation, Pearson correlation, and analysis path.

\section{Results:-}

The analysis of demographic profiles of respondentWith regard to the demographic profiles, from 350 respondents, most were female, followed by male. Most respondent aged 31-40 years, followed by aged less than 30 years, aged 41-50 years, and aged 51-60 years respectively. All respondent always participated in the activities of Buddhist organization. Most works as the employee/personnel in private organization, followed by business owner, officer of government or state enterprise respectively. 
The analysis of attitude towards the management style of Buddhist organizations in Thai society

With regard to the attitude towards the management style of Buddhist organizations in Thai society, most respondents agreed with management of Buddhist organizations in Thai society at the highest level $(\bar{X}=4.28$, S.D. = .37). In particular, International Organizational Management had the highest mean score $(\bar{X}=4.31$, S.D. = .36), followed by PublicWelfare $(\bar{X}=4.30$, S.D.=.53), Non-ProfitOrganization $(\bar{X}=4.29, S . D .=.36)$, andGood Governance $(\bar{X}=4.29$, S.D. $=.60)$ respectively (see table 1$)$.

Table 1:-Mean and standard deviation of the attitude towards the management style of Buddhist organizations in Thai society

\begin{tabular}{|c|c|c|c|}
\hline The management style of Buddhist organizations in Thai society & $\bar{X}$ & S.D. & Attitude level \\
\hline Public Welfare & 4.30 & .53 & highest \\
\hline International Organizational Management & 4.31 & .36 & highest \\
\hline Non-Profit Organization & 4.29 & .36 & highest \\
\hline Good Governance & 4.24 & .60 & highest \\
\hline Total & 4.28 & .37 & highest \\
\hline
\end{tabular}

The correlation between the components of the management style of Buddhist organizations in Thai society With regard to the correlation between the components of the management style of Buddhist organizations in Thai society, the results show that every component had the relationship with statistical significance at level of .01. The correlation was between .39 and .84 .

The highest correlation was a relationship between Non-Profit Organization (NPO) and International Organizational Management(IOM), which its correlation was .84. The lowest correlation was a relationship between Good Governance(GOG) and Public Welfare (PUW), which its correlation was.39 (see table 2).

Table 2;-The correlation between components of the management style of Buddhist organizations in Thai society

\begin{tabular}{|c|c|c|c|c|c|c|}
\hline variables & $\overline{\mathrm{X}}$ & S.D. & PUW & IOM & NPO & GOG \\
\hline PUW & 4.26 & .45 & 1.00 & & & \\
\hline IOM & 4.21 & .43 & $.62^{* *}$ & 1.00 & & \\
\hline NPO & 4.17 & .46 & $.65^{* *}$ & $.84 * *$ & 1.00 & \\
\hline GOG & 4.22 & .45 & $.39 * *$ & $.50^{* *}$ & $.50^{* *}$ & 1.00 \\
\hline
\end{tabular}

$* *$ with statistical significance at level of .01

The analysis of components of the management style of Buddhist organizations in Thai society

With regard to the statistics value to evaluate the concordance of the model after the modification indices, the results show that Chi-square Probability Level was .057, CMIN/DF was 1.111, GFI was .948, and RMSEA was .015. All these 4 statistics value passed the evaluation (see table 3).

Table 3:-The statistics value to evaluate the concordance of the model comparing before and after the modification indices

\begin{tabular}{|l|l|c|c|}
\hline $\begin{array}{c}\text { Statistics } \\
\text { value }\end{array}$ & \multicolumn{1}{|c|}{ Criteria for consideration } & $\begin{array}{c}\text { Before the } \\
\text { modification }\end{array}$ & $\begin{array}{c}\text { After the } \\
\text { modification }\end{array}$ \\
\hline Chi-square & Do not have the statistical significance(p > .05) & .000 & .057 \\
\hline CMIN/DF & Less than3 & 1.965 & 1.111 \\
\hline GFI & Not less than. 90 & .668 & .948 \\
\hline RMSEA & Less than. 08 & .043 & .015 \\
\hline
\end{tabular}

Therefore, the management model of Buddhist organizations in Thai society after the modification indices was relevant to the empirical data at very good level. Considering the component weight, the results show that Public Welfare (PUW)had a direct influence on International Organizational Management (IOM) with the component weight at .32; had a direct influence on Non-Profit Organization (NPO) with the component weight at .33;had a direct influence on Good Governance (GOG)with the component weight at .43; and had an indirect influence on International Organizational Management (IOM) and Non-Profit Organization (NPO) via Good Governance (GOG). In addition, Good Governance (GOG)had a direct influence on International Organizational Management (IOM) 
with the component weight at .58; and had a direct influence on Non-Profit Organization (NPO)with the component weight at .48 (see figure 2 ).

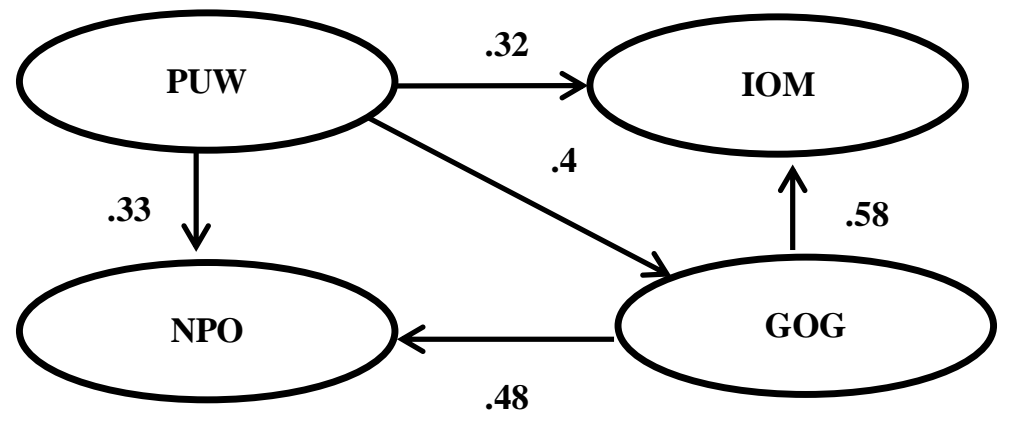

$* \mathrm{p}<.05$ Chi-square $=467.793, \mathrm{df}=421, \mathrm{p}=.057, \mathrm{CMIN} / \mathrm{DF}=1.111, \mathrm{GFI}=.948, \mathrm{RMSEA}=.015$

Figure 2:-The management model of Buddhist organizations in Thai society after the modification indices.

\section{Discussion:-}

The research results show that the management model of Buddhist organizations in Thai societyin the aspect of Public Welfare (PUW), the component with the highest mean score was to provide assistance to the sufferer as much as you can. This is relevant to the study of Inpech (2010), who studied about the roles played by Buddhist monk in social development:a case study of PhrathepSakornmuni (KaewSuvanajoto), that the public welfare is the operation of the enterprise for the public benefit or places that is the public property of general people. In case that the villagers are not ready to operate by themselves, the monk, as the community leader, should take the role to give initial suggestions about what should be done in the community for the common benefit. The appropriateness and circumstance should be necessarily recognized in operatingthe public welfare. In addition, it is also relevant to the teaching methods or the public welfare operation of the Buddha, according to PhrakhruPariyatThammawong (2015), Buddha had His methods to declare, to tell, and to explain so that the learners understand and realize by themselves and they can help themselves to survive through physical and mental suffering. One of His methods is to teach only the necessary things that is sufficient for the learner to understand that topic. Moreover, this is relevant to the study of PhrakhrubaidikaSuraphonAsabho (Yaemchum) (2014), who studied about the model development of public welfare based on Buddhist paradigm, that public welfare was one of the important tasks of the monk to help villagers, general people in order to facilitate appropriate conveniences in the merit making.This is also relevant to the study of PhrakhruWisutthanantakhun(SurasakVisuddhacaro) (2014) that the monastery administration for Buddhism stability of Thai Sanghain the aspect of public welfarewas proposed as5M's model; 1) M1 : Man, 2) M2 : Money, 3) M3 : Materials, 4) M4 : Management,and 5) M5 : Morality. These are the appropriate and effective monastery administration. It wasup to the abbots who were the forefront administrators to manage the monasteries. According to this mentioned discussion, Public Welfare (PUW) of Buddhist organization can lead to the International Organizational Management (IOM), by being the Non-Profit Organization (NPO), which relies on the Good Governance (GOG).

The research results show that the management model of Buddhist organizations in Thai societyin the aspect of International Organizational Management (IOM), the component with the highest mean score wasbeing the organization of the center of faith that can motivate people to practice goodness, followed by defining the power, duty, responsibility according to the command line explicitly. This is relevant to the process of organizing which composes of leading, motivating, persuading organization members to achieve the mission (Bartol and Martin, 1997;Naveekan, 2001). This is also relevant to the management principle in terms of centralization (Fayol, 1949), and the study of PhrakhruPariyatKitjapiwat (2015), who studied about leadership and performance management of public welfare, that leadership and efficiency management of public work in temple required system and good organization style, which consisted of the appropriate personal management, the workingsystem, and other supportive factors. The organizing system should be efficient from the planning system, the work structure system, the personnel management, the assignment, and the capability to control the work. In addition, the researcher also suggests that the research results in this aspect can answer the research result in the past that the temple was disorderly, becomes the source of amulet; some monk does not behave well; thereby people lose faith and do not want to go to the temple. 
The research results show that the management model of Buddhist organizations in Thai societyin the aspect of Non-Profit Organization (NPO), the component with the highest mean score was operating the public welfare without seeking for the profit, followed by managing the budget in transparent and verifiable method. This is relevant to the concept of Chansom (2012) that the non-profit organization would not focus on generating the profit, but its financial goal is to achieve the objective of organization foundation. Regarding the temple, as one of the kind of non-profit organization, its target is to be the religious place, the mind center of Buddhist, the place for doing religious activities, including the residence for monk. Although the temple does not work for profit, it must have appropriate directions for financial management following the financial management principles of non-profit organization for the transparency in operation which can be verified.According to Supajakwattana (2011), in addition that the non-profit organization must not seek for the profit, and should rely on the basis of organizational management, organizational design, performance assessment, including the qualifications of executives who have to work for others without expecting any return or profit. Above all, the most important is honesty and responsibility at the highest level. Moreover, the operation of non-profit organization must be transparent as well as the governance of government organization. People must be able to always verify the operation about assistance provision to the disadvantaged and the budget management in order to reduce the problem about money laundering and corruption. The researcher thought that this shows an important conflict issue in the organization about the non-profit operation. In contrast, nowadays most temples do not make the account recording and financial report correctly.

The research results show that the management model of Buddhist organizations in Thai societyin the aspect of Good Governance (GOG), the component with the highest mean score was treating people with gentle manner, followed by performing the mission in good faith, sincerity, and loyalty. This is relevant to the concept of Uwanno (1999) that one of the important principles about good governance was that the performer must rely on accuracy, sense of duty; must be honest, sincere, diligent, and patient; and must have discipline and respect others' right. According to Uwanno (2008), good governance in Buddhism is Dasavidha-rājadhamma ("tenfold virtue of the ruler"), especially in the aspect of Maddava, which means kindness, gentleness, humbleness, politeness, being gracefulto be devoted and respected; and Ājjava, which means honesty and artless; operating mission with honesty and sincerity. This is also relevant to the study of PhramahaRittichaiYanitiko (Namsombat) (2016), who studied about temple management in good governance, the management according to the good governance principles in responsiveness method consisted of the capability to provide quality services, and to finish the operation within the specified period to create reliability and trust. This is also relevant to the principle about disclosure, transparency; by that the operation must be transparent and verifiable, and that the useful news and information must be disclosed to be acknowledged thoroughly. According to the mentioned discussion, Good Governance (GOG) in the Buddhist organization can lead to Non-Profit Organization (NPO) which contains honesty, sincerity, and loyalty, which leads to International Organizational Management (IOM) that can create trust and reliability to the society.

The hypothesis results also show that public welfare, international organizational management, non-profit organization, and good governance were the important components of the management of Buddhist organization in Thai society.

\section{Recommendations:-}

The researcher presented the recommendations in each component, as follows;

Regarding the public welfare, it should focus on teaching people to know, to understand, and to realize. The teaching methods should be appropriate to the learners in order to receive real results so that people can be self-reliant at last.

Regarding the international organizational management, it should focus on always verifying the performance of every department in the organization, and making a report of the work and publicize it to the public in order to upgrade the standard of Buddhist organization to be reliable and to be the role model to other social organization.

Regarding the non-profit organization, it should focus on managing the organization with the middle way, and performing the mission with volunteerism in order to create good new image to the Buddhist organization in Thai society.

Regarding the good governance, it should focus on sacrificing happiness for the benefit and peace of the country, including behaving well, comprehending body, words, and mind to be respected in order to create reliability and faith to the organization in the society of materialism. 


\section{References:-}

1. Bartol, K. M., and Martin, D. C. (1997). Management. ( $2^{\text {nd }}$ ed.). New York: McGraw - Hill.

2. Chansom, N. (2012). Buddhist Thai Temples' Financial Management: The Congruence of Good Governance Principles. Complete Report, Graduate School of Development Economics, National Institute of Development Administration (NIDA).

3. Department of Religious Affairs. (1985). Guide to Educational Administration of the Sangha. ( $2^{\text {nd }}$ ed.). Bangkok: Kansatsana Printing House.

4. Drucker, P. (2006). Classic Drucker: Wisdom from Peter Drucker from the Pages of Harvard Business Review. Boston: Harvard Business Review Press.

5. Fayol, H. (1949). General and Industrial Management. Martino Fine Books.

6. Gulick, L., and Urwick, L. (1937). Papers on the Science of Administration. New York, NY: Columbia University Press.

7. Inpech, I. (2010). The Roles Played by Buddhist Monk in Social Development: A Case Study of Phrathepsakornmuni (KaewSuvanajoto). Masterof Arts (BuddhistStudies), Mahachulalongkornrajavidyalaya University.

8. Kaewchamnong, A. (2011). The Principles of Management. ( $3^{\text {rd }}$ ed.). Songkhla: NamsilpKosana.

9. Kaewphichit, S. S. (2008). The practice of good governance in private higher education institutes. Dissertation. Doctor of Philosophy (Educational Administration), Silpakorn University.

10. Khwanmuang, S. (2005). Good governance. Journal of Education Studies, 12 (3), 7.

11. Lohmann, R.A. (2007). Charity, Philanthropy, Public service, or Enterprise: What are the big questions of Nonprofit Management today?. Public Administration Review, 67(3), 437-444.

12. Luckert, K. (n.d.). Nonprofit Organization $\mathrm{s}$ (Definition and Examples). Retrieve from http://learningtogive.org/papers/papers41.html.

13. McNamara, C. (n.d.). Basic Overview of Nonprofit Organizations. Retrieve from http://managementhelp.org/org_thry/np_thry/np_intro.htm\#anchor247079.

14. National Statistical Office. (2017). Demographic Statistics, Population and Housing. Retrieve from http://statbbi.nso.go.th/staticreport/page/sector/th/01.aspx

15. Naveekan, S. (2001). Strategic Management. Bangkok: Bannakit.

16. PhraAkanitSiripanyo (Artwichai). (2011). Public Assistant Management of Sangha Administrators in Muang District, Pathumthani Province. Thesis. Master of Arts (Buddhist Management), Mahachulalongkornrajavidyalaya University.

17. PhraBrahmagunabhorn (P.A. Payutto). (2014). Dictionary of Buddhism. (27 ${ }^{\text {th }}$ ed.). Bangkok: Mahachulalongkornrajavidyalaya Publishing.

18. PhraBrahmapundit (PrayoonDhammacitto). (2015). Reform of Buddhist Affairs. ( $3^{\text {rd }}$ ed.). Bangkok: Mahachulalongkornrajavidyalaya Publishing.

19. PhrakhrubaidikaSuraphonAsabho (Yaemchum). (2014). Development of a Public Welfare Model in Buddhist Paradigm. Dissertation. Doctor of Philosophy (Buddhist Management), Mahachulalongkornrajavidyalaya University.

20. PhrakhruPariyatKitjapiwat. (2015). Leadership and Performance Management of Public Welfare. Dissertation. Doctor of Public Administration, Mahachulalongkorn-rajavidyalaya University.

21. PhrakhruPariyatThammawong. (2015). Buddha as the Almoner. Retrieve from http://202.28.110.169/mcukk/uploads/eresearcher/upload_doc/2015/academic/1428680927571360002558.pdf.

22. PhrakhruWisutthanantakhun (SurasakVisuddhacaro). (2014). Monastery Administration for Buddhism Stability. Dissertation. Doctor of Philosophy (Buddhist Management), Mahachulalongkornrajavidyalaya University.

23. PhramahaRittichaiYanitiko (Namsombat). (2016). Temple management in good governance: case study of WatSaketRachaWoraMahaWihara, PomPrapSattruPhai District, Bangkok. Thesis. Master of Public Administration. Sripatum University.

24. PhrathepPariyatsuthi (WorawitKhongkhapanyo). (2002). Handout for lecturing about Sangha and Buddhism. Bangkok: Mahachulalongkornrajavidyalaya Publishing.

25. Preechapermprasit, D. (2015). Buddha's Speech in Buddha's Residence. Bangkok: AmarinDhamma.

26. Prime Minister's Office. (1999). Regulations of the Office of the Prime Minister on Creating a good governance system for the country and society, B.E.2542 (1999).

27. Prutipinyo, C. (2010). Principle of Social Research. Bangkok: CharoendeeMankong Publishing.

28. Schermerhorn, John R. (1999). Organizational Culture and Leadership. ( $2^{\text {nd }}$ ed). San Francico: Jossey Bass.

29. Serirat, S. et al. (2002). Organization and Management. Bangkok: Dhammasan. 
30. Sheldrake, J. R. (1996). Management Theory from Taylorism to Japanization. London: International Thompson Business Press.

31. Sornmanee, C. (n.d.). Meaning of non-profit organization. Retrieve from http://www.mbastou.org/images/column_1237195965.

32. Supajakwattana, P. (2011). Nonprofit organization: P.A. knowledge forgotten in Thailand. FEU Academic Review, 4(2), 51-60.

33. Suwanmongkol, P.(2015). Public administration and good governance creation. Bangkok: King Prajadhipok's Institute.

34. Uwanno, B. (1999). Creation of Good Governance in Thai Society. Bangkok: Vinyuchon.

35. Uwanno, B. (2002). Good Governance in Independent Organization. Handout for lecturing on $8^{\text {th }}$ June 2002. Nonthaburi: King Prajadhipok's Institute.

36. Uwanno, B. (2008). Personal research document on creation of good governance. Bangkok: National Defence College of Thailand. 